\title{
Niche partitioning and densities of Albertine Rift endemics and their congeners in Bwindi Impenetrable Forest, Uganda
}

\author{
Philip Shaw
}

School of Biology, Bute Building, University of St Andrews, Fife, KY16 9TS. United Kingdom

e-mail: ps61@st-andrews.ac.uk

\section{ABSTRACT}

Biogeographical theory predicts that restricted-range species should typically occur at lower densities than ecologically similar, but geographically widespread species. Exceptions may arise where endemics occupy distinctive habitats, in which they are capable of reaching higher densities than their more widespread competitors. This paper describes the habitat requirements and abundance of a sample of insectivores in Bwindi Impenetrable Forest, part of the Albertine Rift mountains Endemic Bird Area. The altitude ranges, habitat preferences, foraging niches and densities of five Albertine Rift endemics from the genera Phylloscopus, Apalis, Batis and Parus were compared with those of their sympatric congeners, or with ecologically similar species. The five endemics were associated with ridgetop forest, steeply sloping ground and a sparse understorey or field layer. They foraged within a narrower height range and used a wider range of substrates than their partner species, but showed no significant differences with regard to altitude range, the number of habitat features with which they were associated, foraging niche width or population density. Two endemic apalises were among the most abundant of their genus, achieving densities at least seven times that of the least abundant apalis at Bwindi. These findings are broadly consistent with results from studies of other montane bird communities in Africa, which suggest that bird species endemic to Afromontane forests often achieve densities comparable with those of widespread, ecologically similar species, and may thus avoid the 'double jeopardy' of small range size and low population density.

Keywords: Albertine Rift; Afromontane; endemic; niche; density; Phylloscopus; Apalis; Batis; Parus 


\section{INTRODUCTION}

Foraging niche width and overlap within forest bird communities has been well studied, particularly in the north temperate zone and in parts of the Neotropics (Gibb 1954, Orians 1969, Pearson 1971, MacArthur 1972, Cody 1974, Wiens 1989, Greenberg 1981, Mara and Remsen 1997). Small insectivorous passerines generally minimise interspecific competition by selecting different foraging heights (MacArthur 1972, Walther 2002), forest strata (Pearson 1971), substrates (Morse 1978) or feeding techniques (MacArthur 1972, Cody 1974). Taken together, these and other parameters define a species' foraging niche: the $n$ dimensional space in which it operates more efficiently than its local competitors. Where two species have similar niches they may minimise competition by occupying mutually exclusive geographic or altitudinal ranges (Terborgh 1977) or territories (Sæther 1983), or by shifting their respective niches, such that one better complements the other (Herrera 1978, Hogstad 1978, Alatalo 1981, Alatalo et al. 1987).

These adaptations have been well documented in European and North American forest songbird communities, which are usually dominated numerically by a relatively few warbler (Sylviidae, Parulidae), tit (Paridae) or finch (Fringillidae) species. Tropical rain forest communities are typically much more species-rich, so greater levels of niche 'packing' are likely (Klopfer and MacArthur 1961), requiring species to specialise to a greater degree, and perhaps limiting their local abundance. Since population density and geographic range size tend to be positively correlated (Gaston and Lawton 1988, Gaston et al. 1997), bird species classed as 'restricted-range' (occupying a global range of up to $50,000 \mathrm{~km}^{2}$ : Stattersfield et al. 1998) are likely to occur at lower densities than the more widespread, ecologically similar species with which they overlap. Restricted-range species may therefore suffer a double jeopardy: being endemic to a small area and scarce within it.

Exceptions may arise where the endemic species' preferred habitat is sufficiently distinctive, enabling it to reach similar or higher densities than widespread sympatrics (Gaston and Lawton 1990). Thus, Reif et al. (2006) found no significant relationship between the density and geographic range size of montane endemics, other montane species, and non-montane bird species in the Bamenda Highlands, Cameroon. They showed that montane species occupied wider niches and hence were better adapted to local environmental conditions than non-montane species, and suggested that a similar pattern is likely to arise in other Afromontane forests.

The Albertine Rift mountains Endemic Bird Area (EBA) consists of a chain of montane forest fragments running north-south along the western edge of Uganda, Rwanda, Burundi and 
Tanzania, and the eastern edge of the Democratic Republic of Congo (Stattersfield et al. 1998). The EBA is thought to cover some $56,000 \mathrm{~km}^{2}$, although the true extent of some of its forests and the status of their avifauna remain poorly known, due in part to the continuing political instability affecting much of the region (Kanyamibwa 2000, Plumptre et al. 2007). In common with other Afromontane sites, the area's high levels of endemicity have been attributed to long-term climatic stability, enabling biogeographically relictual species (e.g. Pseudocalyptomena, Hemitesia and Graueria) to persist, while promoting the adaptive radiation of younger, restricted-range taxa (Fjeldså and Lovett 1997). The EBA's forest fragments include Bwindi Impenetrable Forest, SW Uganda, which supports 24 restrictedrange species, four of which are globally threatened (Stattersfield et al. 1998).

This paper describes the habitat associations, foraging niches and densities of a sample of small, relatively abundant, insectivorous passerines in Bwindi Impenetrable Forest. Foraging niches and population densities were examined within the genera Phylloscopus, Apalis, Batis and Parus, to determine whether the niche widths and densities of five Albertine Rift endemics differ significantly from those of their sympatric congeners or ecologically similar species.

\section{STUDY AREA AND METHODS}

Bwindi Impenetrable National Park, SW Uganda, occupies an area of $331 \mathrm{~km}^{2}$, spanning an altitude range of 1 160-2 607m a.s.l. (McNeilage et al. 2001). The terrain is varied and rugged, comprising narrow valleys separating steep-sided hills, the latter typically reaching $c$. $1400 \mathrm{~m}$ in the northern sector and c. $2600 \mathrm{~m}$ in the south. The structure and composition of the forest vegetation is strongly influenced by local topography, and has been classified as ridgetop, hilltop, hillslope, gully and valley floor forest (Hamilton 1969). Little of the forest is considered intact however, having been exploited heavily by pit sawyers or subjected to selective logging (McNeilage et al. 2001). In the southern part of Bwindi, ridgetop and hilltop forest occurs mainly above c. $2000 \mathrm{~m}$, where the canopy reaches c. 10-15m. Bamboo occurs above $2330 \mathrm{~m}$, and becomes dominant above c. $2420 \mathrm{~m}$. Valley floor forest occurs mainly below $2000 \mathrm{~m}$, and is characterised by well-spaced mature trees with a canopy height of $20-25 \mathrm{~m}$, emergents reaching $30-35 \mathrm{~m}$ or more. Rain falls in all months of the year at Bwindi, peaking mainly in September-November and February-April, and averaging 1 440mm per annum (Collar and Stuart 1988). 
Habitat associations and population densities of selected species were determined from timed point counts made in the wet season, in October 1999 (145 points) and NovemberDecember 2002 (156 points). Fieldwork during 1999 was limited to an area of c. 8x8 km in the vicinity of the Institute of Tropical Forest Conservation (ITFC) Research Station at Ruhija $\left(29^{\circ} 46^{\prime} \mathrm{E}, 1^{\circ} \mathrm{O} 2^{\prime} \mathrm{S}\right)$, in the southern part of the forest (Shaw and Shewry 2001). In 2002 two further areas were surveyed, yielding the following combined samples: Ruhija, 201 survey points at $2030-2520 \mathrm{~m}$; Buhoma, 70 points at $1480-1880 \mathrm{~m}$; and 'the Neck', 30 points at $1480-1560 \mathrm{~m}$. Survey points were located at intervals of $150 \mathrm{~m}$, mainly along tracks and paths. During 1999 alternate survey points were located 50m from the nearest track or path, to determine the impact these features may have on each species' abundance and habitat associations.

The species surveyed were small, predominantly insectivorous passerines from three foraging guilds: probers and gleaners (tits: Parus); leaf gleaners (warblers: Sylviidae; whiteeyes: Zosterops); and flycatchers (batises: Batis). Each guild included at least one Albertine Rift endemic occurring at Bwindi in sufficient numbers to yield adequate sample sizes for the purpose of determining habitat associations, population density and foraging niche characteristics. Point counts yielded sufficient data to determine the habitat associations and population densities of 14 and 11 warbler species, respectively. Since the latter included two endemic Apalis and one endemic Phylloscopus species, foraging niche data were collected for these warbler genera, as well as for the tits and batises.

\section{Habitat associations}

At each survey point the following features were recorded: altitude (to the nearest $20 \mathrm{~m}$ ); forest type (ridgetop/hilltop, hillside, valley floor); slope (shallow $\left(<30^{\circ}\right)$ or steep) and the presence (within $50 \mathrm{~m}$ ) of a stream, track or footpath. Vegetation cover (sparse $(<33 \%)$, moderate (33-66\%), dense) was recorded for each of the following strata: canopy, understorey, bamboo layer, upper field-layer, lower field-layer (i.e. forest floor).

Encounters with each study species were recorded over a 10-minute period at each point, commencing at least two minutes after arriving at the location. Features associated with each species' presence at survey points were identified using a logistic regression model in Systat 7.0 (Steinberg and Colla 1997). Habitat categories for which sample sizes were small were combined with an adjoining category, and a forward, stepwise model was fitted. Habitat and topographic variables were retained in the model if the probability associated with their alpha 
value was less than 0.10 . Interactions between retained variables were added to the model, and were then retained or rejected according to the same criterion.

\section{Density estimates}

Each bird's distance from the survey point when first detected was measured using an electronic rangefinder, by pacing or by estimation (for distances of less than $18 \mathrm{~m}$ ). Distances to birds that were only heard or poorly seen were estimated by measuring the distance to vegetation immediately in front of and behind the bird. Such detections were assigned to distance bands five- or $10 \mathrm{~m}$ wide for birds less than $100 \mathrm{~m}$ from the observer, or $20 \mathrm{~m}$ wide for distances exceeding $100 \mathrm{~m}$. Distances were normally measured to each individual, rather than to the estimated centre of a group. However, where groups were poorly seen the group size was assumed to be the average recorded for that species, based on casual observations. Although the true variance in group size is likely to have been underestimated, this is rarely a major component of the variance of the overall population estimate. Based on points surveyed in 1999, Shaw and Shewry (2001) showed that detection rates declined towards midday, but that counts made during the latter part of the morning improved precision, without lowering density estimates. Accordingly, observations were made from $07 \mathrm{~h} 00$ through to $14 \mathrm{~h} 00$.

Densities were estimated using Distance V4.0, Release 1. All detections were grouped into distance intervals, the boundaries of which were selected so as to dampen the effects of rounding errors (Buckland et al. 1993). The full range of models provided by Distance was fitted in each case, and the most appropriate detection function was selected using the Akaike Information Criterion. In three cases, data for species with small sample sizes were pooled with those of a congener. A detection function was then generated for each pair of congeners, rather than for individual species. This approach was used in the case of the two Parus species, two Batis species and for two apalises: Grey Apalis Apalis cinerea and Buffthroated Apalis A. rufogularis.

\section{Foraging niche width and overlap}

Each species' foraging niche was assessed by recording the location and behaviour of a focal individual when it was first encountered, and thereafter at intervals of at least one minute. When first located, or re-found, the individual's behaviour was noted after a 5 s delay, to minimise any bias towards recording unusually conspicuous behaviour or feeding positions. The following parameters were recorded: height of bird (in $3-5 \mathrm{~m}$ bands), tree 
height, stratum (upper canopy, lower canopy, understorey, upper field layer, lower field layer), substrate (outer tips, twigs, branch, trunk, hanging vine, bamboo stem) and foraging method used (search, glean, sally-glean, probe, fly-catch, handle prey). Several observations were normally recorded from one or a group of individuals before they were lost from sight. Since consecutive observations made during an encounter were non-independent, both the number of observations and the number of encounters are given as an indication of sample size (Figure 1).

The width of each species' foraging niche was calculated using the reciprocal of Simpson's index:

$W=1 /\left(\Sigma p i^{2}\right)$

where $\mathrm{W}$ is a measure of width and $\mathrm{p} i$ is the proportion of observations in which the species was recorded in category $i$ of parameter $p$ (Colwell and Futuyma 1971). This calculation was made for each of five parameters: foraging height, stratum, substrate, method used and altitude (in four bands). The five indices were summed to give an overall index of niche width. Niche overlap between pairs of species was calculated as:

$\alpha=\Sigma$ piqi $\sqrt{ }\left(\Sigma p^{2} \Sigma q i^{2}\right)$

where $\alpha$ is an index of overlap between species $p$ and $q, p i$ is the proportion of observations of species $\mathrm{p}$ in the ith category, and $\mathrm{q} i$ is the proportion of observations of species $q$ in the $i$ th category of the chosen parameter (Pianka 1973). Niche overlap was calculated for each parameter in turn, and then summed to give an overall measure of overlap between each species pair.

\section{RESULTS}

\section{Habitat associations}

Habitat associations of 18 insectivores were determined from detections made at 301 survey points (Table 1). They included six Albertine Rift endemics and 13 out of 20 warbler species usually or always associated with forest habitats at Bwindi (Kalina and Butynski 1996). The most widespread species, Chestnut-throated Apalis A. porphyrolaema and Mountain-masked Apalis $A$. personata, were each detected at $25 \%$ of survey points, while the least widespread, 
Olive-green Camaroptera Camaroptera chloronota, was detected at only $3 \%$ of points, much of the area surveyed lying above its altitude range. Five other forest warbler species (Evergreen Forest Warbler Bradypterus lopezi, Mountain Yellow Warbler Chloropeta similis, White-chinned Prinia Prinia leucopogon, White-browed Crombec Sylvietta leucophrys and Short-tailed Warbler Hemitesia neumanni) were detected, but too infrequently for inclusion in the analysis.

Detection rates for 14 of the 18 species surveyed varied significantly with altitude, 10 species being encountered more frequently at higher altitudes (Table 1). Since the variable 'altitude' is likely to mask the influence of ecological factors with which it is correlated it was subsequently excluded from the model. Two versions of the model were then run: incorporating all survey points (i.e. spanning the full range of altitudes surveyed); and incorporating only those survey points within the species' altitude range at Bwindi, as determined during the course of the study. Topographic features were more often selected in the first of these models than in the second, suggesting that such features were likely to have influenced the species' altitude range. For example, low altitude species were more often associated with 'hillside or valley floor' forest, and high altitude species with 'ridgetop' forest (Table 1), these features being more prevalent at low and high altitudes, respectively.

Although the 18 species examined were collectively associated with a wide range of feature types, five of the six Albertine Rift endemics showed a preference for relatively few features: ridgetop forest, steeply sloping ground and a sparse understorey or field layer (Table 1). In some cases, closely related species were associated with complementary habitat features, Rwenzori Batis Batis diops being associated with ridgetop forest, while Chinspot Batis $B$. molitor was associated with hillside or valley floor forest. Similarly, Grey Apalis was positively associated with paths or tracks, where the canopy is likely to be broken, while Chestnutthroated, Buff-throated and Rwenzori Apalis A. ruwenzorii were associated with an absence of paths or tracks. In most cases, however, there was no clear complementarity between the broad habitat features selected by congeners, suggesting that niche partitioning was partly dependent on fine-scale factors, such as foraging height, strata or substrate, within a shared micro-habitat.

To gauge the strength of each species' association with features selected in the logistic regression analyses, a preference index was calculated, as follows; survey points were separated into those at which all of the species' preferred features were present, and those at which one or more preferred features were absent. The proportion of points at which the species was encountered was then calculated for each set of points. Thus, Rwenzori Apalis 
was encountered at $71 \%$ of points where all of its preferred features were present, and at $25 \%$ of points where one or more preferred features were absent. The species' preference index was therefore 2.9 , indicating that it was almost three times as likely to be encountered at locations meeting all of its requirements, than at locations meeting some or none of its requirements.

Most of the species surveyed were c. 2-6 times more likely to be encountered at locations where all of their requirements were met (Table 2). There were no obvious characteristics linking species with strong preferences (Dusky Tit Parus funereus, Grey Apalis, Cinnamon Bracken Warbler Bradypterus cinnamomeus) or those with weaker preferences (Mountainmasked Apalis, Grauer's Warbler Graueria vittata), other than a tendency for the latter to forage in the lower vegetation layers.

\section{Density estimates}

Yellow White-eye Zosterops senegalensis was the most abundant species present (200 birds $\mathrm{km}^{-2}$; Table 3), and occurred throughout the altitude range surveyed. Warbler densities varied widely within their respective altitude ranges, reaching extremes in the genus Apalis; for instance, Rwenzori Apalis was about 11 times more abundant than Black-throated Apalis A. jacksoni.

Stripe-breasted Tits $P$. fasciiventer were encountered only above $2,000 \mathrm{~m}$, where they occurred at an estimated density of 23.2 birds km ${ }^{-2}$ (CLs: $11.4-47.3$ birds km-2). However the species was encountered almost six times more often at survey points along tracks and paths than at points further into the forest. Separate estimates were made for these two situations, and suggested a density of 32.1 birds $\mathrm{km}^{-2}$ along tracks and paths, but only 5.7 birds $\mathrm{km}^{-2}$ at points $50 \mathrm{~m}$ into the forest. Since tracks and paths were over-represented in the sample the overall population density of Stripe-breasted Tits is likely to have been much lower than the initial estimate (23.2 birds $\mathrm{km}^{-2}$ ) suggests. Based on an approximate estimation of the area of land within $50 \mathrm{~m}$ of tracks or paths in the vicinity of Ruhija, the tit's density is likely to have been of the order of 8 birds $\mathrm{km}^{-2}$ overall.

\section{Foraging niches}

Foraging niche widths and overlap were calculated for five Albertine Rift endemics, and compared with those of seven congeners or ecologically similar species. 


\section{Apalises}

Foraging niche overlap between pairs of apalis species was high, reaching between 4.3 and 4.7, where a score of 5.0 indicates an identical foraging niche (Table 4). Nonetheless, the six apalis species showed distinct differences in their preferred foraging heights, strata and altitude ranges (Figure 1). Three species (Black-throated, Grey and Chestnut-throated Apalis) foraged mainly in the upper canopy, but were separated partly by altitude. While Black-throated Apalis were more commonly encountered at mid-altitude survey points (at $c .2$ 000-2 100m), Chestnut-throated Apalis occurred mainly above this level, and Grey Apalis mainly below it (Figure 1). Buff-throated Apalis were also predominantly canopy feeders, but divided their time more equally between the canopy and understorey. While Mountainmasked Apalis foraged in all five strata, they were observed mainly in the understorey, where they overlapped with Buff-throated Apalis. Competition between these two species may have been limited partly through differences in altitude range and foraging height. In contrast, Mountain-masked and Rwenzori Apalis occupied a similar altitude range and foraged mainly within the same height band $(0-5 \mathrm{~m})$, but used different strata, Rwenzori Apalis foraging almost exclusively in the field layer (Figure 1).

Shaw et al. (2005) have shown that tail length in the genus Apalis is strongly linked to preferred foraging strata, the mean tail length of canopy dwellers being $10 \%$ longer than that of generalist species that occupy a wide range of strata. The latter, in turn, had a mean tail length $10 \%$ longer than species associated with the understorey or field layers. To determine whether this pattern was evident among the six apalis species at Bwindi, the ratio of tail:tarsus length (from Urban et al. 1997) was compared with the percentage of observations during which each species was seen foraging in the canopy. These measures were strongly correlated, $\left(r^{2}=0.911 ; P=0.003\right)$, the three canopy feeders having proportionately longer tails than the mid-strata Buff-throated Apalis and the two lower strata species, Rwenzori and Mountain-masked Apalis (Figure 2). The six species also varied in their choice of foraging substrate, particularly in their use of the outer tips of foliage, which accounted for between $36 \%$ and $91 \%$ of observations (for Rwenzori and Buff-throated Apalis, respectively). There was, however, no apparent relationship between foraging substrate and each species' preferred strata.

The cumulative distribution of encounters with each apalis species varied markedly in relation to altitude, three patterns being evident (Figure 3). The cumulative percentage of Grey and Buff-throated Apalis encountered rose sharply between 1480 and $1800 \mathrm{~m}$, extending to $1840 \mathrm{~m}$ and $2040 \mathrm{~m}$ respectively. In contrast, Chestnut-throated and Rwenzori 
Apalis were recorded only above $2040 \mathrm{~m}$, both showing a steep, steady increase up to 2 $520 \mathrm{~m}$. Black-throated and Mountain-masked Apalis were present almost throughout the range surveyed, but showed a much slower rate of increase at lower altitudes, where they overlapped with Grey and Buff-throated Apalis, and a more rapid increase above $2040 \mathrm{~m}$, in the absence of these two species.

\section{Tits}

Both tit species foraged mainly in the canopy, Stripe-breasted Tits occupying a wider range of strata, which occasionally included the field layer or ground. Stripe-breasted Tits also showed a slightly greater but non-significant tendency to forage on tree trunks and limbs (25\%; $n=203$ observations) than Dusky Tit (17\%; $n=108$ observations). Despite their shared preference for the canopy the two species foraged at very different heights, Dusky Tits feeding mainly above 15-20m and Stripe-breasted Tits mainly below that level (Figure 1). These differences are likely to reflect tree height differences within their altitude ranges, Dusky Tits occurring mainly below $2000 \mathrm{~m}$, near to watercourses, where the canopy tends to be much higher. The two tit species thus overlapped mainly in their choice of foraging substrate and stratum (Table 4), and least in terms of altitude (Figure 3). Encounters recorded throughout the study indicate an altitudinal overlap of at least $170 \mathrm{~m}$ (Table 1), encompassing the lower $38 \%$ of the Stripe-breasted Tit's range and the upper $22 \%$ of the Dusky Tit's range. During timed point counts, 39\% of Stripe-breasted Tits and 33\% of Dusky Tits were found within this overlap zone.

\section{Batises}

Chinspot and Rwenzori Batis were separated by their choice of foraging heights and strata, the former spanning a wider range of perch heights and foraging mainly in the canopy (82\% of observations) (Figure 1). In contrast, 94\% of Rwenzori Batis foraging observations were made in the field layer or understorey, $84 \%$ being below $5 \mathrm{~m}$.

\section{Red-faced Woodland Warbler Phylloscopus laetus}

This species was recorded between 1560 and 2 500m, but was encountered with greater frequency near the upper end of its range. It foraged mainly in the understorey and lower canopy, rarely above c. 15m (Figure 1). Observations on Willow Warbler P. trochilus, one of two Palearctic congeners occurring at Bwindi (Kalina and Butynski 1996), suggest that the latter forages mainly in the canopy, but was present only in small numbers. A much more abundant potential competitor is the resident, similar-sized Yellow White-eye (Table 3), which occurs throughout the altitude range of Red-faced Woodland Warbler, foraging at similar heights but within a wider range of strata (Figure 1). 


\section{Abundance and niche widths of restricted-range species}

The following measures were compared to determine whether the population densities or habitat preferences of Albertine Rift endemics differed significantly from those of their more widespread counterparts: altitude range; the number of habitat or topographical features with which each species was associated; the strength of their habitat preferences; the range of foraging heights, strata, substrates and methods used; foraging niche width; and population density. Since insufficient data were available for the two Palearctic Phylloscopus warblers, Red-faced Woodland Warbler was instead compared with Yellow White-eye. For each of these measures, five restricted-range species were thus compared with seven congeners or partner species (Table 4).

Four of the five restricted-range species typically foraged mainly in the understorey or field layers. As a group, they occupied a narrower range of heights than their partner species (Mann Whitney $U_{5,7}=1.0 ; P=0.003$ ), but used a wider range of substrates (Mann Whitney $\left.\mathrm{U}_{5,7}=5.0 ; \mathrm{P}=0.024\right)$. There were no other significant differences between the two groups, i.e. with regard to altitude range, the number of features with which they were associated, their habitat preference indices, foraging strata, methods, or foraging niche width. Similarly, there were no significant differences between the population densities of four endemics and their six congeners, or between five endemics and 11 non-endemic species (Table 3).

\section{DISCUSSION}

Biogeographical theory predicts that restricted-range species should typically occur at lower densities than ecologically similar but geographically widespread species (Gaston and Lawton 1988, Gaston et al. 1997). Exceptions are likely to occur in particularly distinctive habitats, such as montane rain forest, where endemic species may achieve higher local densities than sympatric generalists (Gaston and Lawton 1990). In this study, five insectivores endemic to the Albertine Rift varied widely in terms of their population density in Bwindi Impenetrable Forest. As a group, they were no more or less abundant than 11 ecologically similar species, most of which belonged to the same genera as the endemics. Two Albertine Rift endemics (Stripe-breasted Tit and Rwenzori Batis) were less common than their congeners, while two others (Rwenzori and Mountain-masked Apalis) were among the most abundant of their genus, achieving densities at least seven times that of the least abundant apalis (Table 3). Note, however, that the five endemics were selected in part 
because of their abundance and ease of detection, and in this respect differ from most of the Albertine Rift endemics present at Bwindi.

These findings are broadly consistent with results from studies of other Afromontane bird communities, in which endemic taxa have been reported to be 'common', 'fairly common' or else among the most abundant of their genus or foraging guild. Examples include Nyungwe Forest, Rwanda (Dowsett-Lemaire 1990), the Taita Hills, Kenya (Brooks et al. 1998), Namuli Massif, Mozambique (Ryan et al. 1999), the Rwenzori Mountains, Uganda (Dehn and Christiansen 2001a), the Eastern Arc Mountains, Tanzania (Romdal 2001, Tøttrup et al. 2004), Western Angola EBA (Ryan et al. 2004), the Virunga Volcanoes (Owiunji et al. 2005) and the Bamenda Highlands (Reif et al. 2006, Sedláček et al. 2007). Taken together, these studies suggest that many bird species endemic to Afromontane forests achieve densities comparable with those of widespread, ecologically similar species, and may thus evade the 'double jeopardy' of small range size and low population density.

For most species, the density estimates presented here were similar to those reported from an earlier survey, based on observations made above 2 030m (Shaw and Shewry 2001). Exceptions were Stripe-breasted Tit, Banded Prinia and Mountain-masked Apalis, the two warblers being encountered less frequently at the lower altitudes surveyed in this study (Table 3).

Since the majority of point counts were made along tracks or paths, the densities of species associated with broken canopy or forest edge habitats may have been over-estimated. The Stripe-breasted Tit, for example, is strongly associated with tracks and paths (Shaw and Shewry 2001; this study), where they occurred at an estimated density of 32.2 birds $\mathrm{km}^{-2}$. This accords well with an estimate of 30 birds $\mathrm{km}^{-2}$ in the vicinity of the ITFC Field Station at Ruhija, where most individuals have been colour-ringed as part of an on-going study (pers. obs.). In contrast, survey points $50 \mathrm{~m}$ into the forest yielded an estimate of just 5.7 birds $\mathrm{km}^{-2}$, and the overall density (above $2000 \mathrm{~m}$ ) was thought to be $c .8$ birds $\mathrm{km}^{-2}$.

Bwindi provides a continuum between lowland and montane forest types (Bennun 1986), spanning an altitude range of $1447 \mathrm{~m}$. However the maximum altitude reached $(2607 \mathrm{~m})$ is low in comparison with that of most other montane forests in the Albertine Rift. Of the six endemics listed in Table 1, all but one (Grauer's Warbler) reach higher altitudes elsewhere in their range. Since the population density of montane species normally varies with altitude (e.g. Terborgh 1977, Dehn and Christiansen 2001b, Romdal 2001, Owiunji et al. 2005), the estimates presented here may not be representative of the same species in forests that reach higher altitudes elsewhere in the Rift. Indeed, in the Virunga Volcanoes, Owiunji et al. 
(2005) encountered Red-faced Woodland Warbler up to 36\% more often and Stripe-breasted Tits up to six times more often at altitudes higher than those reached at Bwindi.

\section{Niche partitioning}

Cody (1974) noted that tropical congeners occupy exclusive altitudinal ranges, with no overlap between species pairs. In contrast, altitudinal overlap between congeners was common in this study (Figure 1) as it is in other Afromontane forests, including Nyungwe (Dowsett-Lemaire 1990), the Namuli Massif (Ryan et al. 1999), Rwenzoris (Dehn and Christiansen 2001b), Eastern Arc Mountains (Romdal 2001) and Virunga Volcanoes (Owiunji et al. 2005).

The species surveyed here were collectively associated with a wide range of topographical and habitat features, illustrating the need to preserve the structural diversity and latitudinal range of forest cover at Bwindi. By definition, the conditions favoured by restricted-range species are likely to be met within a small geographical area, suggesting that their habitat requirements may be more specialised. Together, the small number of Albertine Rift endemics examined here were associated with fewer habitat features and foraged within a narrower height range than the non-endemic species, but on a wider range of substrates. However the two groups showed no significant differences with regard to foraging niche width or altitudinal range.

The six sympatric apalis species each showed high levels of niche overlap with at least one congener. The two endemic apalis species are short tailed, foraged mainly in dense vegetation below $10 \mathrm{~m}$ and occupied similar altitude zones, but selected different strata: the understorey (Mountain-masked Apalis) and field layers (Rwenzori Apalis). Three long tailed apalis species foraged mainly in the upper canopy (Figure 1), but reached peak densities at differing altitudes, being most abundant either in the high- (Chestnut-throated Apalis), mid(Black-throated Apalis) or lower altitude zone (Grey Apalis).

Despite using almost identical foraging methods (fly catching), the two batis species showed a lower index of overlap than was evident among pairs of apalis species, or between Redfaced Woodland Warbler and Yellow White-eye (Table 4). The latter is mainly insectivorous, and while it also takes nectar and fruit, in other respects showed a high level of niche overlap with Red-faced Woodland Warbler: greater than was evident between the two tits, batises and several pairs of apalises (Table 4), suggesting that competition with the white-eye could limit the warbler's abundance at Bwindi. 
All five of the restricted-range species examined in detail foraged mainly in lower vegetation strata or at lower heights than their more widespread congeners, this separation being particularly marked in the case of Rwenzori and Chinspot Batis (Figure 1). Red-faced Woodland Warbler also foraged in lower strata than its (migrant) congener, the Willow Warbler, which at Bwindi forages mainly in the lower canopy (pers. obs.). In addition, Bwindi's two remaining restricted-range forest warblers - the monotypic Grauer's Warbler and Short-tailed Warbler - also forage in the understorey or field layers. Taken together, these findings might suggest a link between foraging niche and endemicity; canopy dwellers perhaps having greater dispersal abilities. There was, however, no evidence of such a link among the warbler species; while all six endemic forest warblers forage in the understorey or field layers, 17 of Bwindi's 21 widespread forest warbler species also occur mainly in the lower strata (Fisher's Exact test; n.s.) (Kalina and Butynski 1996, Urban et al. 1997).

Findings from this study support the view that large-scale correlations between global range size, population density and habitat specialisation may not translate into clear trends at the local level. However, it is also possible that any underlying patterns at Bwindi were masked by small sample size: of the species, conditions and altitudes surveyed. Recent climate change projections suggest that much of Africa will experience higher temperatures by 2080-90 (Boko et al. 2007). These are likely to impact on the structure and altitudinal ranges of montane forests, which are assumed to have a particularly low adaptive capacity (Anon. 2007). In the light of these predicted changes, the Albertine Rift's high human population densities, and their high dependence on subsistence agriculture (Plumptre et al. 2004), further surveys are needed to determine the current altitudinal ranges, niche widths and abundance of its endemic species.

\section{ACKNOWLEDGEMENTS}

I am grateful to the Uganda Wildlife Authority and the Uganda National Council for Science and Technology for granting permission for this study to proceed. I also wish to thank Derek Pomeroy and two anonymous reviewers for their comments on the manuscript, Alastair McNeilage for providing accommodation and field support at Ruhija, and Narsensius Owoyesigire and Godfrey Myooba for their assistance in the field. 


\section{REFERENCES}

Anon. 2007. Biodiversity in the Albertine Region: Baseline Assessment Report. Report by the Institute of Resource Assessment, Pan-African START Secretariat (PASS) and University of Dar es Salaam, Tanzania

Alatalo, RV 1981. Interspecific competition in tits Parus spp. and the goldcrest Regulus regulus: foraging shifts in multispecific flocks. Oikos 37: 335-344

Alatalo, RV, Eriksson, D, Gustafsson, L and Larsson, K 1987. Exploitation competition influences the use of foraging sites by tits: experimental evidence. Ecology 68(2): 284290

Bennun, LA 1986. Montane birds of the Bwindi (Impenetrable) Forest. Scopus 10: 87-91

Boko, M, Niang, I, Nyong, A, Vogel, C, Githeko, A, Medany, M, Osman-Elasha, B, Tabo, R and Yanda, P 2007. Africa. In: Parry, ML, Canziani, OF, Palutikof, JP, van der Linden, PJ and Hanson CE (eds.) Climate Change 2007: Impacts, Adaptation and Vulnerability. Contribution of Working Group II to the Fourth Assessment Report of the Intergovernmental Panel on Climate Change. Cambridge University Press, Cambridge, UK \& New York, USA

Brooks, T, Lens, L, Barnes, J, Barnes, R, Kageche Kihuria, J, Wilder, C 1998. The conservation status of the forest birds of the Taita Hills, Kenya. Bird Conservation International 8: 119-139

Buckland, ST, Anderson, DR, Burnham, KP and Laake, JL 1993. Distance sampling: estimating abundance of biological populations. Chapman and Hall, London

Cody, ML 1974. Competition and the Structure of Bird Communities. Princeton University Press, Princeton

Collar, NJ and Stuart, SN 1988. Key forests for threatened birds in Africa. International Council for Bird Preservation (Monograph No. 3), Cambridge

Colwell, RK and Futuyma, DJ 1971. On the measurement of niche breadth and overlap. Ecology 52: 567-576

Dehn, M and Christiansen, L 2001a. Comments on the occurrence of 15 Albertine Rift endemic bird species in the Rwenzori Mountains National Park, western Uganda. Scopus 22: 13-21

Dehn, M and Christiansen, L 2001b. Altitudinal distributions of congeneric forest bird species in the Rwenzori Mountains National Park, western Uganda. Scopus 22: 29-35 
Dowsett-Lemaire, F 1990. Eco-ethology, distribution and status of Nyungwe Forest birds (Rwanda). In Dowsett, RJ (ed.) Enquête faunistique et floristique dans la Forêt de Nyungwe, Rwanda. pp. 31-85. Tauraco Research Report No. 3. Tauraco Press, Jupille-Liêge, Belgium

Fjeldså, J and Lovett, JC 1997. Geographical patterns of old and young species in African forest biota: the significance of specific montane areas as evolutionary centers. Biodiversity and Conservation 6: 325-346

Gaston, KJ and Lawton, JH 1988. Patterns in the distribution and abundance of insect populations. Nature 331: 709-712

Gaston, KJ and Lawton, JH 1990. Effects of scale and habitat on the relationship between regional distribution and local abundance. Oikos 58: 329-335

Gaston, KJ, Blackburn, TM and Gregory, RD 1997. Interspecific abundance-range size relationships: range position and phylogeny. Ecography 20: 390-399

Gibb, J 1954. Feeding ecology of tits, with notes on Treecreeper and Goldcrest. Ibis 96: $513-543$

Greenberg, R 1981. The abundance and seasonality of forest canopy birds on Barro Colorado Island, Panama. Biotropica 13: 241-251

Hamilton, AC 1969. The vegetation of southwest Kigezi. Uganda Journal 32: 157-164

Herrera, CM 1978. Niche-shift in the genus Parus in southern Spain. Ibis 236-240

Hogstad, 0 1978. Differentiation of foraging niche among tits, Parus spp., in Norway during winter. Ibis 139-146

Kalina, J and Butynski, TM 1996. Check-list of the birds of the Bwindi Impenetrable Forest, Uganda. East Africa Natural History Society, Nairobi

Kanyamibwa, S 2000. Etude pilote sur les Zones d'Importance pour la Conservation des Oiseaux (ZICO) au Rwanda. Ostrich 71: 172-174

Klopfer, PH and MacArthur, RH 1961. On the causes of tropical species diversity: niche overlap. American Naturalist 95: 223-226

MacArthur, RH 1972. Geographical Ecology. Harper \& Row: New York

Marra, PP, and Remsen, JV 1997. Insights into the maintenance of high species diversity in the Neotropics: habitat selection and foraging behavior in understorey birds of tropical and temperate forests. Ornithological Monographs 48: 445-483 
McNeilage, A, Plumtre, AJ, Brock-Doyle, A and Vedder, A 2001. Bwindi Impenetrable National Park, Uganda: gorilla census 1997. Oryx 35: 39-47

Morse, DH 1978. Structure and foraging patterns of flocks of tits and associated species in an English woodland during the winter. Ibis 120: 298-312

Orians, GH 1969. The number of bird species in some tropical forests. Ecology 50: 783-801

Owiunji, I, Nkuutu, D, Kujirakwinja, D, Liengola, I, Plumptre, A, Nsanzurwimo, A, Fawcett, K, Gray, M and McNeilage, A 2005. The Biodiversity of the Virunga Volcanoes. WCS Working Paper. Wildlife Conservation Society, New York

Pearson, DL 1971. Vertical stratification of birds in tropical dry forest. Condor 73: 46-55

Pianka, ER 1973. The structure of lizard communities. Annual Review of Ecology and Systematics 4: 53-74

Plumptre, AJ, Davenport, TRB, Behanganac, M, Kityoc, R, Eiluc, G, Ssegawac, P, Ewangoa, C, Meirted, D, Kahindoc, C, Herremans, M, Kerbis Peterhanse, J, Pilgrim, JD, Wilson, M, Languyi, M, Moyer, D 2007. The biodiversity of the Albertine Rift. Biological Conservation 134: 178-194

Plumptre, AJ, Kayitare, A, Rainer, H, Gray, M, Munanura, I, Barakabuye, N, Asuma, S, Sivha, M and Namara, A 2004. The Socio-economic Status of People Living Near Protected Areas in the Central Albertine Rift. Albertine Rift Technical Reports No. 4. Wildlife Conservation Society, New York

Reif, J, Hořák, D, Sedláček, O, Reigert, J, Pešata, M, Hrázský, Z, Janeček, S and Storch, D 2006. Unusual abundance-range size relationship in an Afromontane bird community: the effect of geographical isolation? Journal of Biogeography 33(11): 1959-1968

Romdal, TS 2001. Altitudinal distribution and abundance patterns of bird species in the Eastern Arc Mountains, Tanzania. Scopus 21: 35-54

Ryan, PG, Bento, C, Cohen, C, Graham, J, Parker, V and Spottiswoode, C 1999. The avifauna and conservation status of the Namuli Massif, northern Mozambique. Bird Conservation International 9: 315-331

Ryan, PG, Sinclair, I, Cohen, C, Mills, MSL, Spottiswoode, CN and Cassidy, R 2004. The conservation status and vocalizations of threatened birds from the scarp forests of the Western Angola Endemic Bird Area. Bird Conservation International 14: 247-260

Sæther, B-E 1983. Habitat selection, foraging niches and horizontal spacing of Willow Warbler Phylloscopus trochilus and Chiffchaff $P$. collybita in an area of sympatry. Ibis 125: 24-32 
Sedláček, O, Reif, J, Hořák, D, Reigert, J, Pešata, M and KIvaňa, P 2007. The birds of a montane mosaic in Big Babanki area, Bamenda Highlands, Cameroon. Malimbus 29: 89100

Shaw, P and Shewry, M 2001. Population density and habitat associations of restricted-range bird species at Ruhija, Bwindi Impenetrable Forest, Uganda. Bird Conservation International 11: 161-174

Shaw, P, Mungaya, E, Mbilinyi, N and Mbilinyi, M 2005. The voice and bill length of Karamoja Apalis Apalis karamojae are atypical of the genus. Bulletin of the British Ornithologists' Club 125(2): 122-129

Stattersfield, AJ, Crosby, MJ, Long, AJ and Wege, DC 1998. Endemic Bird Areas of the World. Priorities for biodiversity conservation. (BirdLife Conservation Series No. 7.) BirdLife International, Cambridge

Steinberg, D and Colla, P 1997. Logistic regression. In: Anon. SYSTAT 7.0. New statistics. SPSS, Chicago

Terborgh, J 1977. Bird species diversity on an Andean elevational gradient. Ecology 58: 1007-1019

Tøttrup, AP, Lennart Larsen, J and Burgess, D 2004. A first estimate of the population size of Loveridge's Sunbird Nectarinia loveridgei, endemic to the Uluguru Mountains, Tanzania. Bird Conservation International 14:25-32

Urban, EK, Fry, CH and Keith, S 1997. The Birds of Africa, Vol. 5. Academic Press, London

Walther, BA 2002. Grounded ground birds and surfing canopy birds: variation of foraging stratum breadth observed in Neotropical forest birds and tested with simulation models using boundary constraints. The Auk 119(3): 658-675

Wiens, JA 1989. The Ecology of Bird Communities. Vol. 1. Functions and Patterns. Cambridge University Press, Cambridge 
Table 1. Habitat features associated with each species' presence at survey points, selected in two logistic regression models: incorporating all survey points, and incorporating only those points within the species' altitude range at Bwindi. Variables are presented in the order in which they were selected in each model. ' $n$ ' $=$ number of points at which the species was detected. Albertine Rift endemics are shown in bold.

\begin{tabular}{|c|c|c|c|c|c|c|c|}
\hline \multirow[t]{2}{*}{ Species } & \multirow[t]{2}{*}{$n$} & \multicolumn{2}{|c|}{ Altitude } & \multicolumn{4}{|c|}{ Features associated with species' presence: } \\
\hline & & range $(\mathrm{m})$ & $r^{*}$ & At all survey points & $P$ & Points within species' altitude range & $P$ \\
\hline $\begin{array}{l}\text { Cinnamon Bracken Warbler } \\
\text { Bradypterus cinnamomeus }\end{array}$ & 23 & $2040-2510$ & + & $\begin{array}{l}\text { Bamboo present } \\
\text { Sparse understorey } \\
\text { Dense upper field layer } \\
\text { Bamboo with sparse understorey }\end{array}$ & $\begin{array}{r}<0.001 \\
<0.000 \\
0.031 \\
0.030\end{array}$ & $\begin{array}{l}\text { Bamboo present } \\
\text { Sparse/moderate understorey } \\
\text { Dense upper field layer } \\
\text { Bamboo with sparse understorey }\end{array}$ & $\begin{array}{r}<0.001 \\
0.004 \\
0.010 \\
0.039\end{array}$ \\
\hline $\begin{array}{l}\text { Black-faced Rufous Warbler } \\
\text { Bathmocercus rufus }\end{array}$ & 19 & $1500-1790$ & - & $\begin{array}{l}\text { Watercourse present } \\
\text { Hillside or valley floor } \\
\text { Dense lower canopy }\end{array}$ & $\begin{array}{r}<0.001 \\
0.005 \\
0.048\end{array}$ & $\begin{array}{l}\text { Watercourse present } \\
\text { Dense lower canopy }\end{array}$ & $\begin{array}{l}0.005 \\
0.040\end{array}$ \\
\hline $\begin{array}{l}\text { Chubb's Cisticola } \\
\text { Cisticola chubbi }\end{array}$ & 53 & $1530-2490$ & + & $\begin{array}{l}\text { Ridgetop } \\
\text { Sparse upper canopy } \\
\text { Bamboo absent }\end{array}$ & $\begin{array}{r}<0.000 \\
0.014 \\
0.030\end{array}$ & $\begin{array}{l}\text { Ridgetop } \\
\text { Sparse upper canopy } \\
\text { Bamboo absent }\end{array}$ & $\begin{array}{r}<0.000 \\
0.014 \\
0.030\end{array}$ \\
\hline $\begin{array}{l}\text { Banded Prinia } \\
\text { Prinia bairdii }\end{array}$ & 58 & $1500-2520$ & & $\begin{array}{l}\text { Sparse/moderate understorey } \\
\text { Track absent } \\
\text { Bamboo present }\end{array}$ & $\begin{array}{r}<0.000 \\
0.004 \\
0.016\end{array}$ & $\begin{array}{l}\text { Sparse/moderate understorey } \\
\text { Track absent } \\
\text { Bamboo present }\end{array}$ & $\begin{array}{r}<0.000 \\
0.004 \\
0.016\end{array}$ \\
\hline $\begin{array}{l}\text { Rwenzori Apalis } \\
\text { Apalis ruwenzorii }\end{array}$ & 63 & $2020-2520$ & + & $\begin{array}{l}\text { Bamboo present } \\
\text { Sparse/moderate upper field layer } \\
\text { Steep slope } \\
\text { Track or path absent } \\
\text { Ridgetop }\end{array}$ & $\begin{array}{r}<0.001 \\
<0.001 \\
0.002 \\
0.047 \\
0.005\end{array}$ & $\begin{array}{l}\text { Bamboo present } \\
\text { Sparse/moderate understorey }\end{array}$ & $\begin{array}{r}<0.001 \\
0.035\end{array}$ \\
\hline $\begin{array}{l}\text { Mountain-masked Apalis } \\
\text { A. personata }\end{array}$ & 75 & $1480-2520$ & + & $\begin{array}{l}\text { Sparse/moderate understorey } \\
\text { Steep slope }\end{array}$ & $\begin{array}{r}<0.001 \\
0.044\end{array}$ & $\begin{array}{l}\text { Sparse/moderate understorey } \\
\text { Steep slope }\end{array}$ & $\begin{array}{r}<0.001 \\
0.044\end{array}$ \\
\hline $\begin{array}{l}\text { Black-throated Apalis } \\
\text { A. jacksoni }\end{array}$ & 15 & $1480-2520$ & & $\begin{array}{l}\text { Shallow slope } \\
\text { Sparse/moderate understorey }\end{array}$ & $\begin{array}{l}0.040 \\
0.051\end{array}$ & $\begin{array}{l}\text { Shallow slope } \\
\text { Sparse/moderate understorey }\end{array}$ & $\begin{array}{l}0.040 \\
0.051\end{array}$ \\
\hline $\begin{array}{l}\text { Chestnut-throated Apalis } \\
\text { A. porphyrolaema }\end{array}$ & 76 & $2040-2520$ & + & $\begin{array}{l}\text { Ridgetop or hillside } \\
\text { Sparse upper field layer } \\
\text { Track or path absent } \\
\text { Moderate/dense lower canopy }\end{array}$ & $\begin{array}{r}<0.001 \\
0.008 \\
0.001 \\
<0.001\end{array}$ & $\begin{array}{l}\text { Moderate/dense lower canopy } \\
\text { Sparse upper field layer } \\
\text { Track or path absent } \\
\text { Ridgetop or hillside }\end{array}$ & $\begin{array}{l}0.001 \\
0.004 \\
0.006 \\
0.002\end{array}$ \\
\hline $\begin{array}{l}\text { Buff-throated Apalis } \\
\text { A. rufogularis }\end{array}$ & 23 & $1480-1840$ & - & $\begin{array}{l}\text { Hillside or valley floor } \\
\text { Dense understorey } \\
\text { Track absent }\end{array}$ & $\begin{array}{r}<0.001 \\
0.010 \\
0.045\end{array}$ & $\begin{array}{l}\text { Few/no breaks in canopy cover } \\
\text { Absence of watercourse }\end{array}$ & $\begin{array}{l}0.025 \\
0.035\end{array}$ \\
\hline $\begin{array}{l}\text { Grey Apalis } \\
\text { A. cinerea }\end{array}$ & 22 & $1480-2380$ & - & $\begin{array}{l}\text { Hillside or valley floor } \\
\text { Path or track present }\end{array}$ & $\begin{array}{r}<0.001 \\
0.023\end{array}$ & Hillside or valley floor & 0.016 \\
\hline $\begin{array}{l}\text { Green-backed Camaroptera } \\
\text { Camaroptera brachyura }\end{array}$ & 20 & $1530-2480$ & & No variables selected & - & No variables selected & - \\
\hline $\begin{array}{l}\text { Olive-green Camaroptera } \\
\text { C. chloronota }\end{array}$ & 9 & $1480-1740$ & - & $\begin{array}{l}\text { Valley floor } \\
\text { Dense understorey }\end{array}$ & $\begin{array}{l}0.008 \\
0.044\end{array}$ & No variables selected & - \\
\hline $\begin{array}{l}\text { Grauer's Warbler } \\
\text { Graueria vittata }\end{array}$ & 42 & $1580-2490$ & & $\begin{array}{l}\text { Sparse/moderate upper field layer } \\
\text { Watercourse absent }\end{array}$ & $\begin{array}{l}0.001 \\
0.010\end{array}$ & $\begin{array}{l}\text { Steep slope } \\
\text { Sparse/moderate upper field layer }\end{array}$ & $\begin{array}{l}0.003 \\
0.023\end{array}$ \\
\hline $\begin{array}{l}\text { Red-faced Woodland Warbler } \\
\text { Phylloscopus laetus }\end{array}$ & 23 & $1560-2500$ & & $\begin{array}{l}\text { Bamboo present } \\
\text { Watercourse absent }\end{array}$ & $\begin{array}{l}0.003 \\
0.043\end{array}$ & Bamboo present & 0.005 \\
\hline $\begin{array}{l}\text { Rwenzori Batis } \\
\text { Batis diops }\end{array}$ & 11 & $1560-2520$ & + & Ridgetop & 0.003 & Ridgetop & 0.014 \\
\hline $\begin{array}{l}\text { Chinspot Batis } \\
\text { B. molitor }\end{array}$ & 16 & $2040-2400$ & + & $\begin{array}{l}\text { Track or path absent } \\
\text { Hillside or valley floor }\end{array}$ & $\begin{array}{l}0.001 \\
0.020\end{array}$ & Track or path absent & $<0.001$ \\
\hline $\begin{array}{l}\text { Stripe-breasted Tit } \\
\text { Parus fasciiventer }\end{array}$ & 12 & $2080-2520$ & + & Sparse understorey & 0.030 & $\begin{array}{l}\text { Track or path present } \\
\text { Sparse understorey }\end{array}$ & $\begin{array}{l}0.054 \\
0.044\end{array}$ \\
\hline $\begin{array}{l}\text { Dusky Tit } \\
\text { P. funereus }\end{array}$ & 12 & $1480-2250$ & - & $\begin{array}{l}\text { Hillside or valley floor } \\
\text { Sparse upper field layer }\end{array}$ & $\begin{array}{l}0.004 \\
0.008\end{array}$ & $\begin{array}{l}\text { Sparse upper field layer } \\
\text { Watercourse present }\end{array}$ & $\begin{array}{l}0.004 \\
0.025\end{array}$ \\
\hline $\begin{array}{l}\text { Yellow White-eye } \\
\text { Zosterops senegalensis }\end{array}$ & 55 & $1500-2500$ & + & $\begin{array}{l}\text { Ridgetop } \\
\text { Bamboo absent }\end{array}$ & $\begin{array}{r}<0.000 \\
0.022\end{array}$ & $\begin{array}{l}\text { Ridgetop } \\
\text { Bamboo absent }\end{array}$ & $\begin{array}{r}<0.000 \\
0.022\end{array}$ \\
\hline
\end{tabular}

* Species showed a significant positive ('+') or negative ('-') correlation with altitude. 
Table 2. The percentage of survey points at which each species was encountered, in relation to whether its habitat preferences (Table 1 ) were (a) fully met or (b) not met or partly met. The preference index $(a / b)$ provides an indication of the strength of the species' preferences.

\begin{tabular}{lccc}
\hline Species & $\begin{array}{c}\text { Encounter rate at points } \\
\text { where preferences were: }\end{array}$ & $\begin{array}{c}\text { Preference } \\
\text { index }\end{array}$ \\
\cline { 2 - 3 } & fully met & partly/ not met & \\
\hline Cinnamon Bracken Warbler & $57.1 \%$ & $6.1 \%$ & 9.4 \\
Black-faced Rufous Warbler & $33.3 \%$ & $6.9 \%$ & 4.8 \\
Chubb's Cisticola & $42.5 \%$ & $13.8 \%$ & 3.1 \\
Banded Prinia & $52.9 \%$ & $17.6 \%$ & 3.0 \\
Rwenzori Apalis & $71.4 \%$ & $24.9 \%$ & 2.9 \\
Mountain-masked Apalis & $36.2 \%$ & $21.6 \%$ & 1.7 \\
Black-throated Apalis & $12.2 \%$ & $2.3 \%$ & 5.3 \\
Chestnut-throated Apalis & $100.0 \%$ & $36.4 \%$ & 2.8 \\
Buff-throated Apalis & $38.9 \%$ & $14.3 \%$ & 2.7 \\
Grey Apalis & $12.1 \%$ & $0.0 \%$ & $*$ \\
Grauer's Warbler & $33.3 \%$ & $17.6 \%$ & 1.9 \\
Red-faced Woodland Warbler & $22.2 \%$ & $7.3 \%$ & 3.1 \\
Rwenzori Batis & $7.6 \%$ & $1.4 \%$ & 5.4 \\
Chinspot Batis & $16.7 \%$ & $3.2 \%$ & 5.1 \\
Stripe-breasted Tit & $16.0 \%$ & $4.9 \%$ & 3.3 \\
Dusky Tit & $50.0 \%$ & $5.1 \%$ & 9.8 \\
Yellow White-eye & $33.7 \%$ & $11.5 \%$ & 2.9 \\
\hline 1 Survey points outside of the species' altitude range were excluded \\
* Grey Apalis was recorded only at points where its preferences were met
\end{tabular}


Table 3. Population density estimates within each species' altitude range.

\begin{tabular}{|c|c|c|c|}
\hline Species & Detections & Density $\left(\mathbf{k m}^{-2}\right)$ & $95 \% \mathrm{CL}$ \\
\hline Cinnamon Bracken Warbler & 31 & 84.6 & $43.9-162.9$ \\
\hline Chubb's Cisticola & 84 & 85.8 & $57.5-127.9$ \\
\hline Banded Prinia & 102 & 106.9 & $75.0-152.2$ \\
\hline Rwenzori Apalis & 90 & 191.1 & $134.5-271.4$ \\
\hline Mountain-masked Apalis & 112 & 120.1 & $85.7-168.4$ \\
\hline Black-throated Apalis & 39 & 17.0 & $9.2-31.3$ \\
\hline Chestnut-throated Apalis & 146 & 180.3 & $134.8-241.2$ \\
\hline Buff-throated Apalis ${ }^{1}$ & 51 & 80.7 & $55.3-178.3$ \\
\hline Grey Apalis ${ }^{1}$ & 53 & 32.8 & $22.2-48.3$ \\
\hline Green-backed Camaroptera & 29 & 40.0 & $20.8-77.5$ \\
\hline Red-faced Woodland Warbler & 29 & 43.3 & $23.9-78.2$ \\
\hline Rwenzori Batis $^{1}$ & 16 & 24.7 & $13.3-46.2$ \\
\hline Chinspot Batis $^{1}$ & 20 & 36.3 & $24.2-54.5$ \\
\hline Stripe-breasted Tit ${ }^{1,2}$ & 22 & 23.2 & $11.4-47.3$ \\
\hline Dusky tit ${ }^{1}$ & 37 & 29.9 & $14.6-60.1$ \\
\hline Yellow White-eye & 116 & 200.7 & $128.2-314.0$ \\
\hline
\end{tabular}

${ }^{1}$ Density estimates were based on a pooled data for the following pairs of congeners: Parus, Batis, Grey and Buff-throated Apalis.

2 Likely to be an over-estimate, due to sampling bias (see text). 
Table 4. Pairs of congeners showing the highest levels of foraging niche overlap.

In some cases the relationship was non-reciprocal, such that species $A$ overlapped most with species $B$, but species B showed greater overlap with another congener. $\Leftrightarrow=$ Reciprocal relationship. $\Rightarrow=$ Nonreciprocal relationship.

\begin{tabular}{llrl}
\hline Species A & \multicolumn{1}{c}{ Species B } & $\begin{array}{c}\text { Overlap } \\
\text { index }\end{array}$ & Overlapping parameters ${ }^{1}$ \\
\hline Grey Apalis & $\Leftrightarrow$ Black-throated Apalis & 4.73 & Stratum, method, height, substrate \\
Buff-throated Apalis & $\Rightarrow$ Grey Apalis & 4.59 & Altitude, method, substrate \\
Chestnut-throated Apalis & $\Rightarrow$ Black-throated Apalis & 4.34 & Substrate, stratum, method \\
Rwenzori Apalis & $\Leftrightarrow$ Mountain-masked Apalis & 4.33 & Substrate, altitude, height \\
Red-faced Woodland Warbler & $\Leftrightarrow$ Yellow White-eye & 4.49 & Height, method, altitude, substrate \\
Rwenzori Batis & $\Leftrightarrow$ Chinspot Batis & 3.47 & Method, substrate \\
Stripe-breasted Tit & $\Leftrightarrow$ Dusky Tit & 3.47 & Substrate, stratum \\
\hline
\end{tabular}

${ }^{1}$ Parameters for which the species pair showed high levels of overlap $(\alpha>0.9)$, listed in descending order of overlap. 


\section{Figure legends}

Figure 1. The heights, strata and altitudes at which 12 insectivores were encountered. Heights and strata were determined from foraging observations. Sample sizes (foraging observations, encounters) are given in brackets. Altitudinal distributions were based on point counts, aggregated into four bands with similar sample sizes. Encounter rate $=$ the mean number of individuals encountered per survey point.

Strata: UC = Upper Canopy, LC = Lower Canopy, US = Understorey, UFL = Upper Field Layer, LFL = Lower Field Layer.

Figure 2. The ratio of tail:tarsus length in male apalises (from Urban et al. 1997), in relation to canopy use (the percentage of observations in which the focal individual foraged in the canopy).

$\mathrm{RA}=$ Rwenzori Apalis, MMA = Mountain Masked Apalis, $\mathrm{BfA}=$ Buff-throated Apalis, GA = Grey Apalis, $\mathrm{BIA}=$ Black-throated Apalis, CTA = Chestnut-throated Apalis.

Figure 3. The cumulative percentage of individuals encountered during timed point counts, in relation to altitude. a.) six apalis species; b.) two tit species. Dotted line: altitudinal limits attained by each tit species throughout the study. 

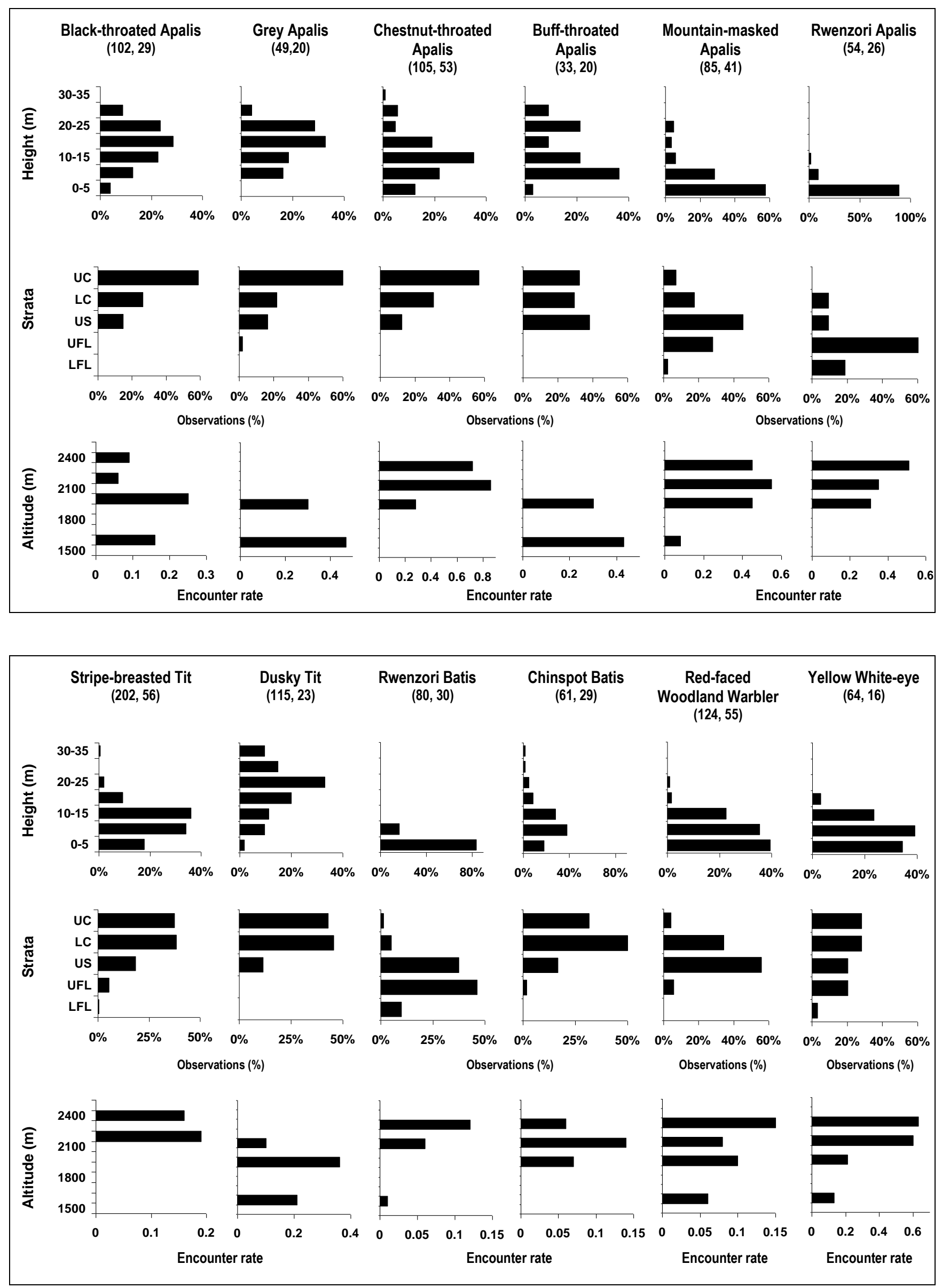
Fig 2

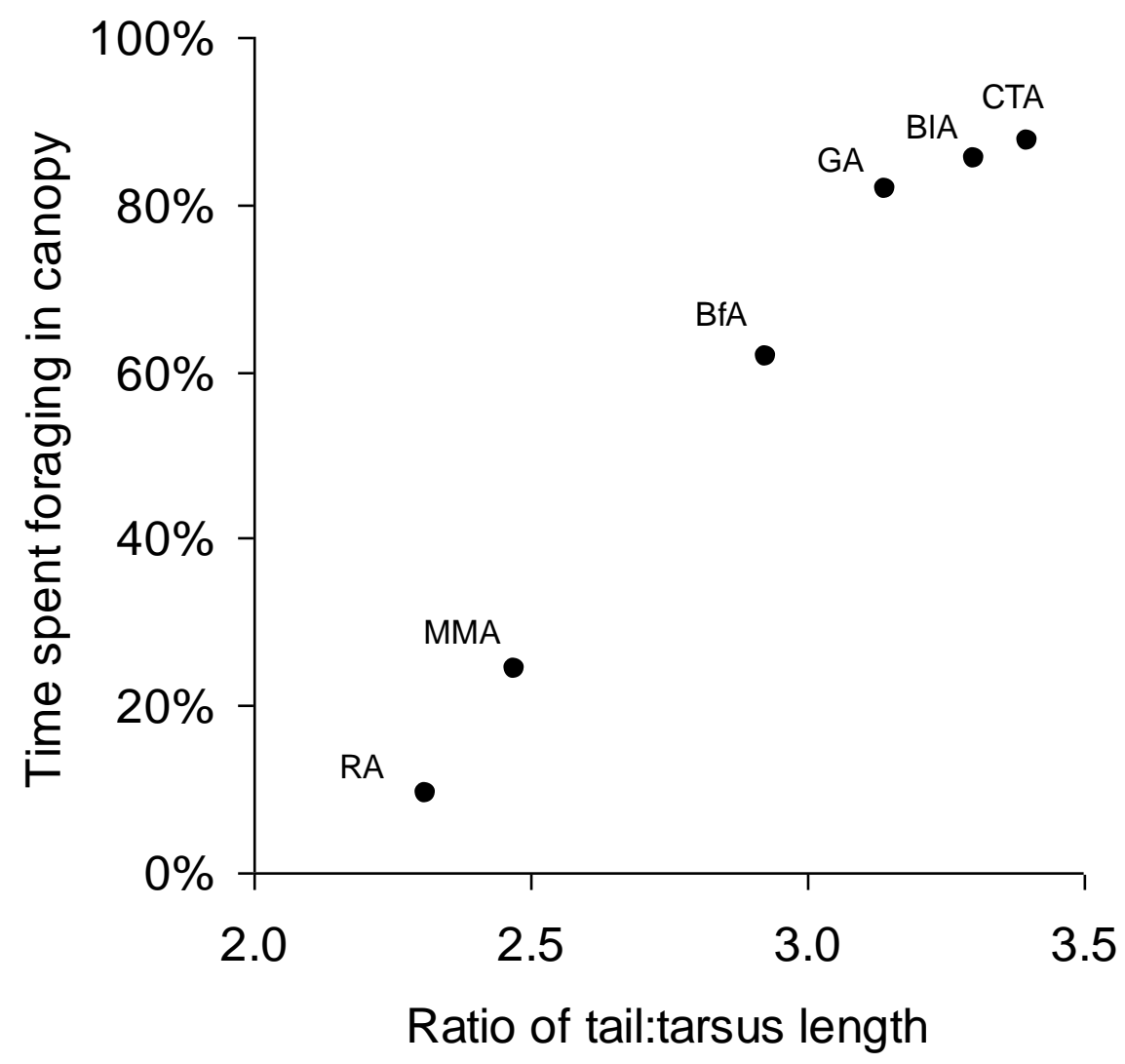


a.

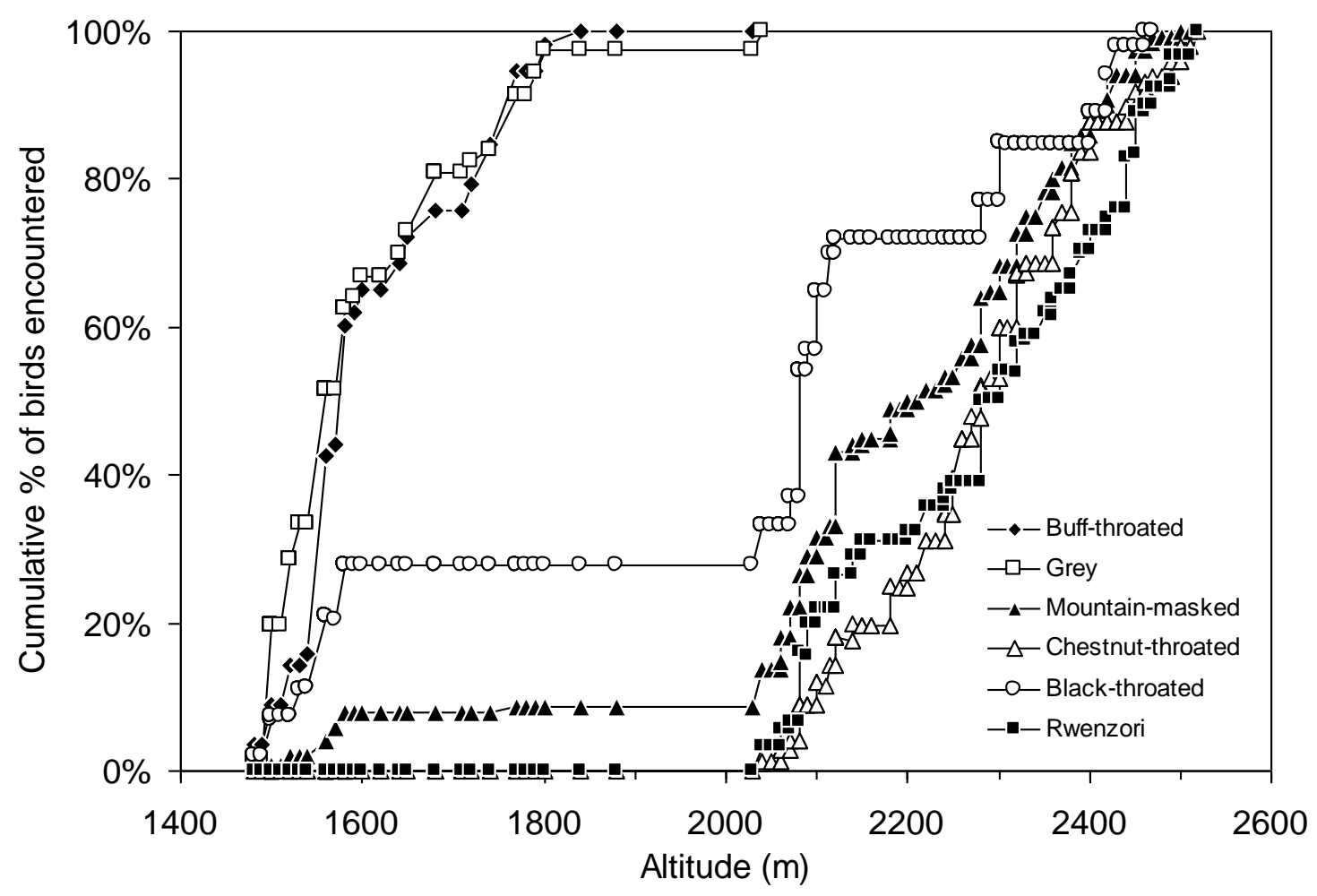

b.

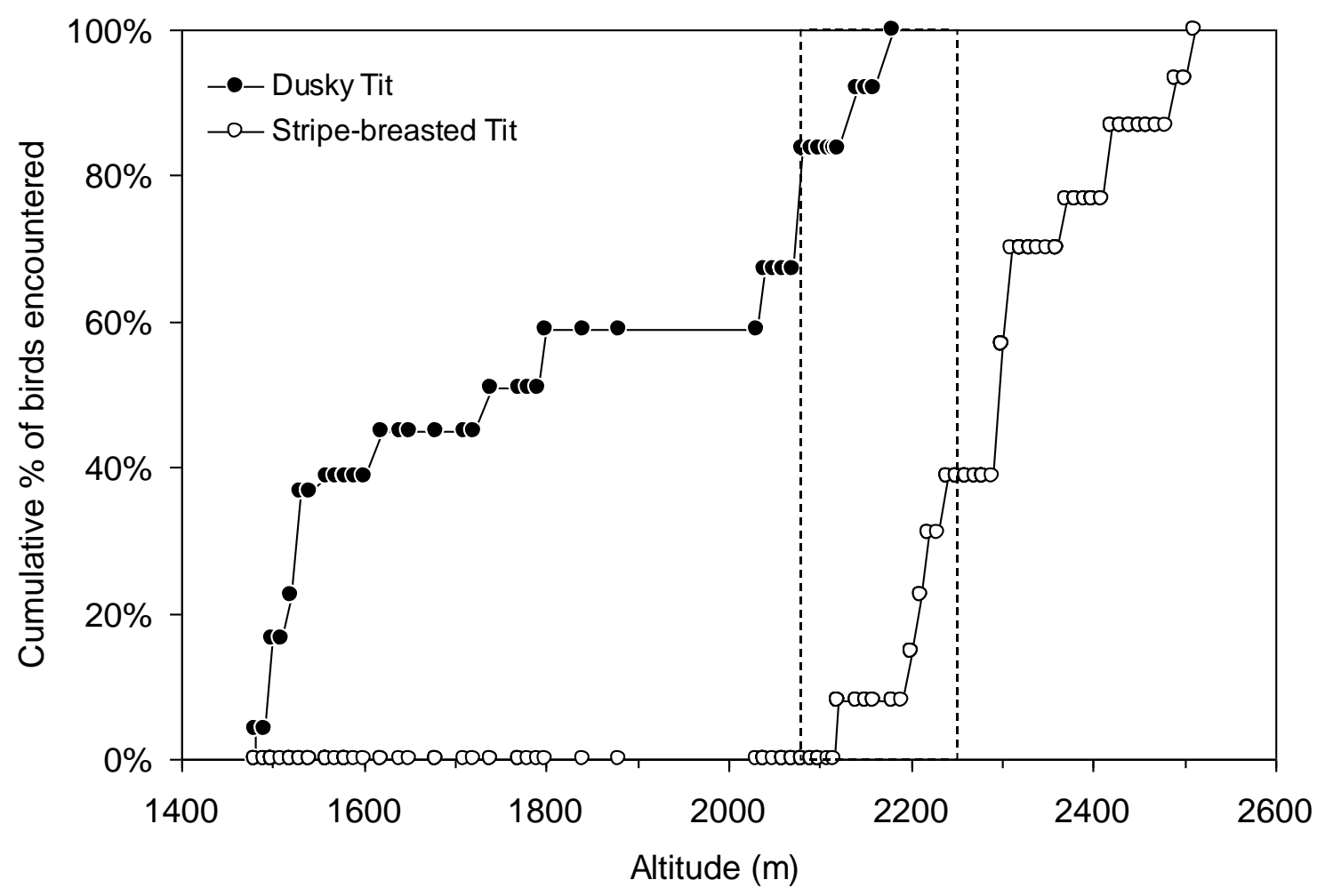

